\title{
Hafnia alvei
}

Hafnia alvei es un bacilo gramnegativo, aeróbico facultativo, móvil gracias a flagelos perítricos, no esporulado. Pertenece a la familia Enterobacteriaceae y al género Hafnia, cuyo único representante es este agente. Su nombre proviene del latín "alveus" que significa colmena ${ }^{1}$.

Se ha encontrado H. alvei en diferentes nichos ecológicos, a nivel ambiental: agua, suelo y alimentos. Además es parte de la microbiota normal de mamíferos, aves, reptiles y peces. En el ser humano ha sido identificado como especie entérica ${ }^{1}$.

Este agente se comporta como patógeno oportunista poco común, que puede causar infecciones nosocomiales ${ }^{2}$, incluyendo gastroenteritis, bacteriemia, neumonía, meningitis, infección de herida operatoria, endoftalmitis y absceso glúteo ${ }^{3}$. Se ha descrito primordialmente en pacientes con cáncer, cirugía, trauma, enfermedad pulmonar aguda o crónica, cirrosis o hepatitis y pancreatitis ${ }^{1}$.
Puede ser aislada de muestras orofaríngeas, gastrointestinales y, con menor frecuencia, de hemocultivos, orina, tejidos y cultivo de catéteres endovasculares ${ }^{1}$.

En la patogenia de $H$. alvei participa el lipopolisacárido (LPS) que corresponde al antígeno O. Según la estructura del LPS de $H$. alvei, se ha dividido en 39 O-serotipos ${ }^{2}$. Una facultad que contribuye a la patogénesis es la captación de hierro mediante sideróforos ${ }^{1}$.

Se identifica al detectar características propias, entre ellas: oxidasa negativo, ser productora de nitrato reductasa y lisina decarboxilasa, ornitina positivo, fermentar varios azúcares entre los que destacan maltosa, D-xilosa, trealosa, D-manitol, L-arabinosa, L-ramnosa, siendo incapaz de fermentar lactosa, rafinosa, D-sorbitol, inositol y adonitol ${ }^{1}$.

Presenta susceptibilidad a antimicrobianos como quinolonas, carbapenémicos, cloranfenicol, aminoglucósidos, monobactam y cotrimoxazol y resistencia a penicilina, oxacilina y amoxicilina/ácido clavulánico. La frecuencia de cepas resistentes es baja ${ }^{1}$.

\section{Referencias}

1.- Janda J M, Abbott S L.The genus Hafnia: from soup to nuts. Clin Microbiol Rev 2006; 19: $12-8$

2.- Mukherjee C, Misra AK. First total synthesis of a pentasaccharide repeating unit of the O-antigen of Hafnia alvei PCM 1529. Glycoconj J 2008; 25 (2): 111-9.

3.- Günthard H, Pennekamp A. Clinical significance of extraintestinal Hafnia alvei isolates from 61 patients and review of the literature. Clin Infect Dis 1996; 22: 1040-5.

Claudia Moreno M. Becada de Microbiología, Universidad de Chile

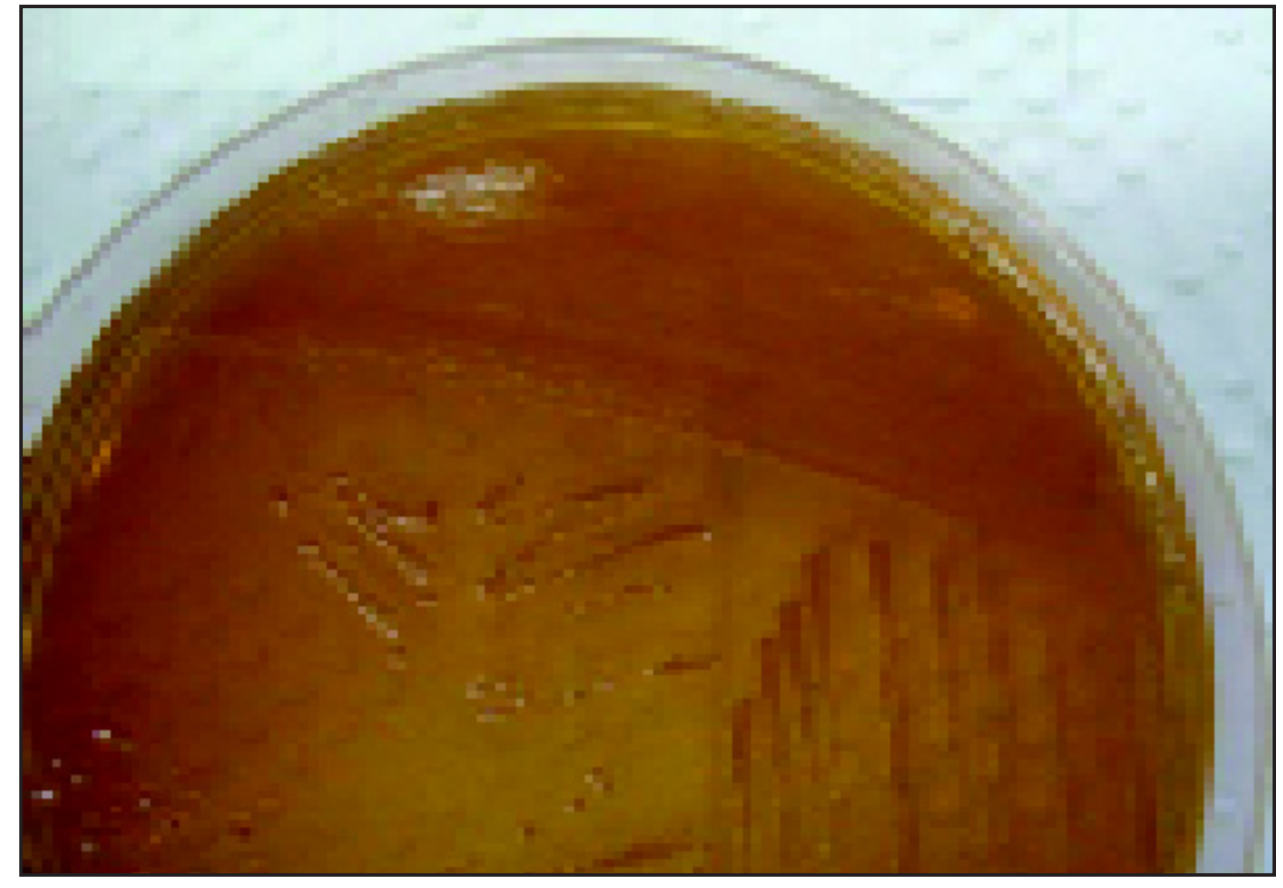

